\title{
Genetics of Magnesium Disorders
}

\author{
Heng $\mathrm{Li}^{\mathrm{a}, \mathrm{c}}$ Shiren Sun ${ }^{\mathrm{b}}$ Jianghua Chen ${ }^{\mathrm{a}}$ Goushuang $\mathrm{Xu}^{\mathrm{b}}$ \\ Hanmin Wang ${ }^{\text {b }}$ Qi Qianc \\ ${ }^{a}$ Kidney Disease Center, The First Affiliated Hospital, College of Medicine, Zhejiang University, Hangzhou, and \\ ${ }^{b}$ Department of Nephrology, Xijing Hospital, The Fourth Military Medical University, Xian, China; ${ }^{\circ}$ Division of \\ Nephrology and Hypertension, Department of Medicine, Mayo Clinic College of Medicine, Rochester, MN, USA
}

\section{Keywords}

Claudins · TRPM6 · Dysmagnesemia · lon channels · Tight junction proteins

\section{Abstract}

Background: Magnesium $\left(\mathrm{Mg}^{2+}\right)$, the second most abundant cation in the cell, is woven into a multitude of cellular functions. Dysmagnesemia is associated with multiple diseases and, when severe, can be life-threatening. Summary: This review discusses $\mathrm{Mg}^{2+}$ homeostasis and function with specific focus on renal $\mathrm{Mg}^{2+}$ handling. Intrarenal channels and transporters related to $\mathrm{Mg}^{2+}$ absorption are discussed. Unraveling the rare genetic diseases with manifestations of dysmagnesemia has greatly increased our understanding of the complex and intricate regulatory network in the kidney, specifically, functions of tight junction proteins including claudin-14, -16, -19, and -10; apical ion channels including: TRPM6, $\mathrm{K}_{\mathrm{v}} 1.1$, and ROMK; small regulatory proteins including $\mathrm{AC} 3$ and ANK3; and basolateral proteins including EGF receptor, $\mathrm{Y}$-subunit (FXYD2) of Na-K-ATPase, $\mathrm{K}_{\mathrm{ir}} 4.1$, CaSR, CNNM2, and SLC41A. Although our understanding of $\mathrm{Mg}^{2+}$ handling of the kidney has expanded considerably in the last two decades, many questions remain. Future studies are needed to elucidate a multitude of unknown aspects of $\mathrm{Mg}^{2+}$

\section{KARGER}

(C) 2017 S. Karger AG, Basel

E-Mail karger@karger.com

www.karger.com/kdd handling in the kidney. Key Message: Understanding rare and genetic diseases of $\mathrm{Mg}^{2+}$ dysregulation has expanded our knowledge and furthers the development of strategies for preventing and managing dysmagnesemia.

(c) 2017 S. Karger AG, Basel

\section{Introduction}

Magnesium $\left(\mathrm{Mg}^{2+}\right)$ is the second most abundant intracellular cation. It carries out multiple and critical functions supporting cellular physiological activities. Sixty percent of the US population, however, show insufficient $\mathrm{Mg}^{2+}$ intake [1], and hypomagnesemia occurs in $~ 30 \%$ of hospitalized patients [2]. The kidney is the principle organ that regulates $\mathrm{Mg}^{2+}$ homeostasis. In the last two decades, a number of new $\mathrm{Mg}^{2+}$ regulatory mechanisms have been uncovered, mainly through investigating patients with rare genetic alterations as the cause of $\mathrm{Mg}^{2+}$

The first two authors contributed equally to this review. It is a contribution from the International Conference: The Kidney in Genetic and Rare Diseases, Naples, October 27-29, 2016. The content was updated and discussed in detail at one of the conferences of the ISN TrioSister Renal Center Program in January 2017.
Qi Qian, MD

Division of Nephrology and Hypertension, Department of Medicine Mayo Clinic College of Medicine, 200 First Street SW

Rochester, MN 55905 (USA)

E-Mail qian.qi@mayo.edu 


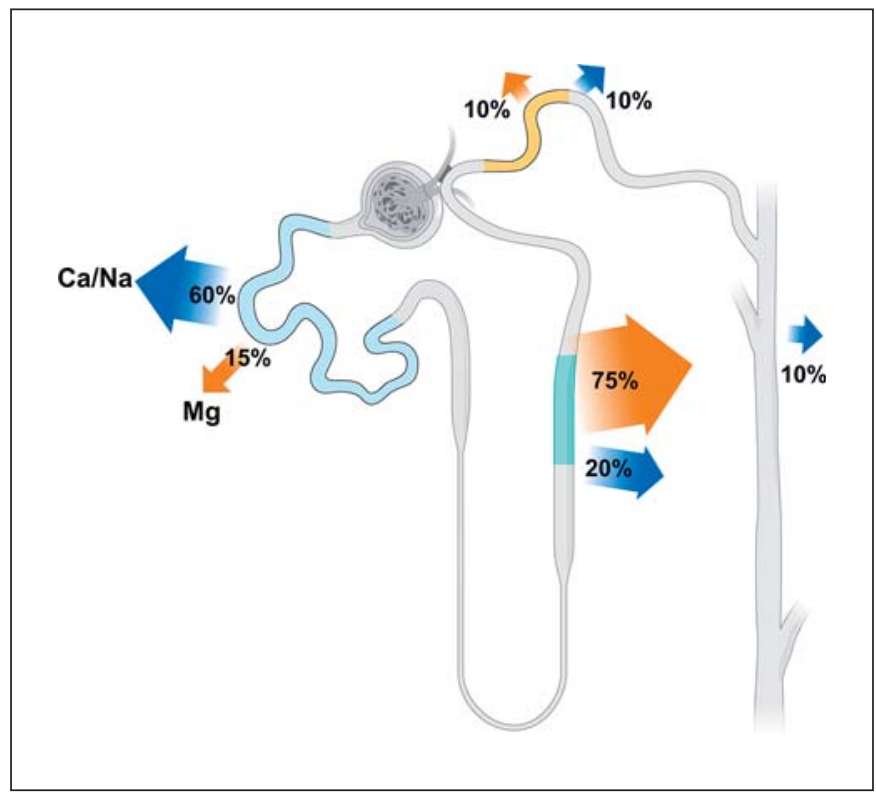

Fig. 1. Renal tubular $\mathrm{Mg}^{2+}$ handling. More than $95 \%$ of the filtered $\mathrm{Mg}^{2+}$ is reabsorbed in the kidney, and only approximately $100 \mathrm{mg}$ of $\mathrm{Mg}^{2+}$ is excreted daily. The distal convoluted tubule is the last part where $\mathrm{Mg}^{2+}$ reabsorption occurs. Beyond that section, the kidney tubules are impermeable to $\mathrm{Mg}^{2+}$.

dysregulation. This review focuses on recent advances in our understanding of $\mathrm{Mg}^{2+}$ regulation in the kidney and dysregulation in patients with specific genetic disorders and poses questions on a number of unresolved issues in this field.

\section{Magnesium Homeostasis and Function}

The medicinal function of $\mathrm{Mg}^{2+}$ was recognized as early as 1618, when in Epsom, England, a farmer realized that his bitter salty well water healed scratches. "Epsom salts" (primarily $\mathrm{Mg}^{2+}$ sulfate) can be found today in any big-box store such as Walmart or Costco and are often used as a bath salt and a remedy for relieving many ailments including joint pain, muscle spasms, abdominal pain, constipation, headaches, and more. Over the years, studies have shown that $\mathrm{Mg}^{2+}$ is a vitally important, indeed a critical, intracellular element. It is a cofactor/coactivator for more than 600 intracellular enzymes and an essential component of DNA replication, RNA transcription, amino acid synthesis, and protein formation. It is also critical and participates in DNA repair including nucleotide excision repair, base excision repair, and mismatch repair. Lack of the inner mitochondrial membrane
$\mathrm{Mg}^{2+}$ channel, Mrs2, leads to respiratory complex I failure and cell death [3]. Additionally, $\mathrm{Mg}^{2+}$ has anti-inflammatory, immunomodulatory, and crystal-inhibitory properties [4]. In the last two decades, genome-wide association studies have shown that polymorphisms in genes related to $\mathrm{Mg}^{2+}$ homeostasis are associated with multiple diseases or risks for diseases including diabetes in African-American and Spanish-American postmenopausal women [1], nephrolithiasis, and reduced bone mineral density [5]. Recently, TRPM7 gene polymorphism has been linked to breast cancer [6]. In addition, studies have shown that $\mathrm{Mg}^{2+}$ alterations can be associated with neurotransmitter defects $[7,8]$ and an array of neurological abnormalities $[9,10]$.

Dietary $\mathrm{Mg}^{2+}$ intake in the general adult population should be in the range of 350-450 mg/day. Fecal excretion of $\mathrm{Mg}^{2+}$ is $\sim 270 \mathrm{mg} /$ day. $\mathrm{Mg}^{2+}$ is absorbed from the gastrointestinal tract, through paracellular transport in the small intestine and transcellular transport in the colon, into the blood, where $\sim 25 \%$ of the absorbed $\mathrm{Mg}^{2+}$ binds to circulating proteins, primarily albumin. The unbound $\mathrm{Mg}^{2+}$ equilibrates with bone and intracellular $\mathrm{Mg}^{2+}$. Intracellular $\mathrm{Mg}^{2+}$ concentrations are in the range of 10-30 mM, and the free cytosolic $\mathrm{Mg}^{2+}$ concentration is $\sim 0.5-1.2 \mathrm{mM}$ [11]. Approximately $70-75 \%$ of the circulating $\mathrm{Mg}^{2+}$ is unbound and is filtered in the kidneys. The glomeruli filter $\sim 2,400 \mathrm{mg}$ of $\mathrm{Mg}^{2+}$ daily. More than $95 \%$ of the filtered $\mathrm{Mg}^{2+}$ is absorbed, leaving a urinary $\mathrm{Mg}^{2+}$ excretion of $\sim 100 \mathrm{mg} /$ day. Predictably, $\mathrm{Mg}^{2+}$ is regulated principally by the kidneys.

\section{Magnesium Absorption in the Proximal Convoluted Tubule}

In contrast to the proximal absorption of calcium $\left(\mathrm{Ca}^{2+}\right)$ and sodium $\left(\mathrm{Na}^{+}\right)$, a relatively small fraction (15\%) of filtered $\mathrm{Mg}^{2+}$ is absorbed in the proximal tubules (Fig. 1) via a paracellular mechanism, although the precise mechanism has not been fully elucidated. In the first portion of the proximal convoluted tubule, $\mathrm{Na}^{+}$, $\mathrm{Ca}^{2+}$, and water are absorbed to a large extent, preceding $\mathrm{Mg}^{2+}$ absorption. When the filtrates reach more distal parts of the proximal tubule, there is an increase in tubular fluid $\mathrm{Mg}^{2+}$ concentration compared to that in the peritubular circulation. When the concentration gradient of $\mathrm{Mg}^{2+}$ between the luminal fluids and the peritubular circulation reaches approximately $1.7-1.9, \mathrm{Mg}^{2+}$ absorption occurs, and is likely driven by the concentration gradient [12].
86

Kidney Dis 2017;3:85-97 DOI: $10.1159 / 000477730$
Li/Sun/Chen/Xu/Wang/Qian 


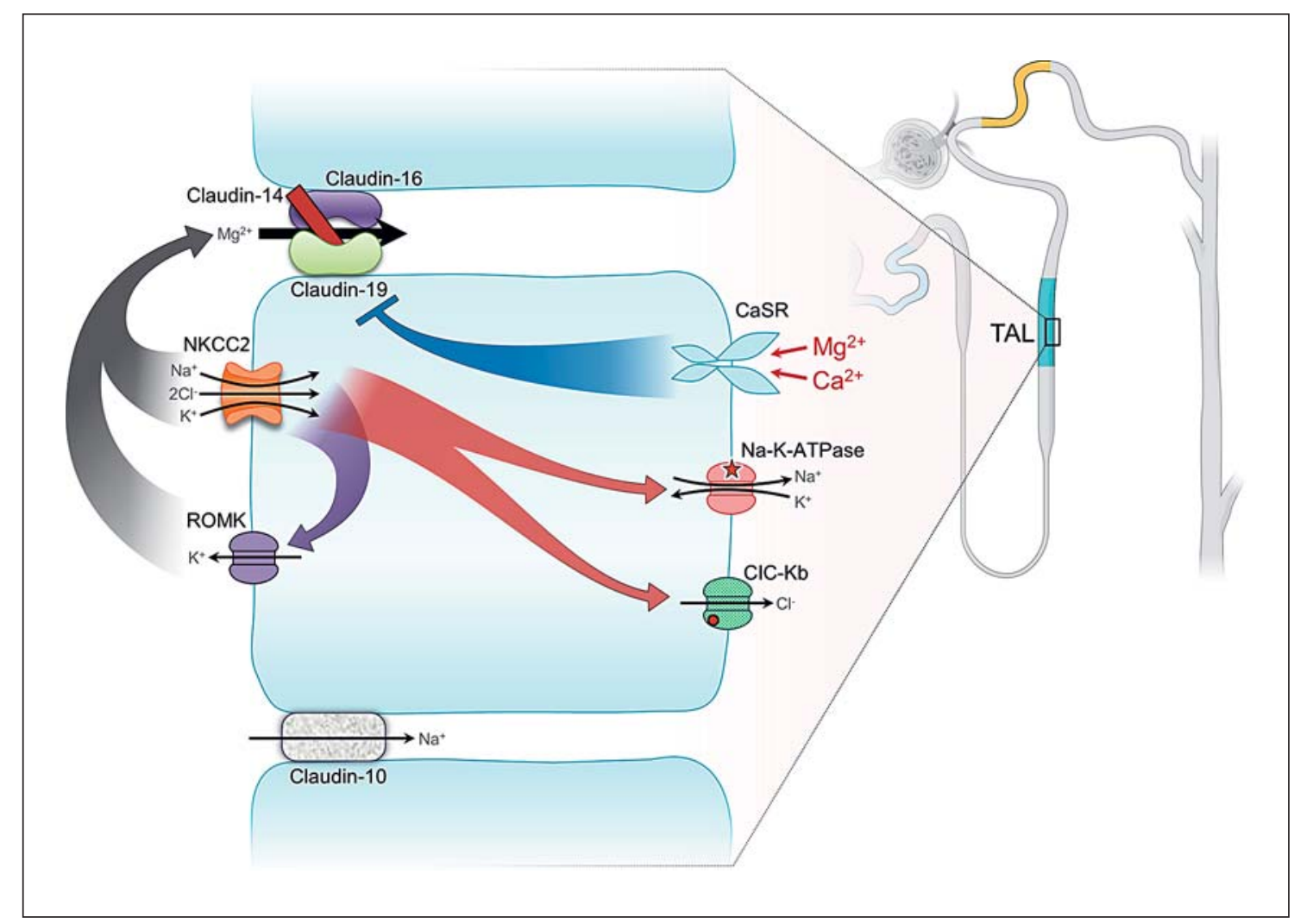

Fig. 2. $\mathrm{Mg}^{2+}$ handling in the thick ascending limb of Henle (TAL). The tight junction proteins claudin-16 and -19 form the $\mathrm{Ca}^{2+}$ - and $\mathrm{Mg}^{2+}$-permeable channel. $\mathrm{Mg}^{2+}$ or $\mathrm{Ca}^{2+}$ in the circulation could activate the basolateral calcium-sensing receptor (CaSR), which exerts inhibitory effects on the tight junction claudin complex. Ba- solateral $\mathrm{Na}-\mathrm{K}$-ATPase provides the driving force for the apical $\mathrm{Na}-\mathrm{K}-2 \mathrm{Cl}$ cotransporter (NKCC2) and parallel $\mathrm{K}^{+}$excretion via ROMK, generating a favorable positive luminal voltage to facilitate paracellular $\mathrm{Mg}^{2+}$ and $\mathrm{Ca}^{2+}$ absorption.

\section{Magnesium Absorption in the Thick Ascending Limb of Henle}

In the thick ascending limb of Henle (TAL), $\mathrm{Mg}^{2+}$ is absorbed paracellularly, facilitated by tight junctional proteins, and the major driving force is the transepithelial voltage gradient. In the initial part of the TAL, the luminal voltage is positive (approx. $+8 \mathrm{mV}$ ), and the $\mathrm{Na}^{+}$and $\mathrm{Cl}^{-}$concentrations are relatively high (Fig. 2). The positive voltage is generated primarily through the apical $\mathrm{Na}-\mathrm{K}-2 \mathrm{Cl}$ cotransporter (NKCC2)-mediated $\mathrm{Na}^{+}, \mathrm{K}^{+}$, and $\mathrm{Cl}^{-}$absorption with parallel $\mathrm{K}^{+}$excretion to the lumen. The driving force for the NKCC2 is the basolateral $\mathrm{Na}-\mathrm{K}$-ATPase. The positive transepithelial voltage gradient propels $\mathrm{Mg}^{2+}$ absorption via paracellular mechanisms. At the distal end of the TAL, where the $\mathrm{Na}^{+}$concentration diminishes, $\mathrm{Mg}^{2+}$ absorption is further regulated by tight junction proteins between the adjacent tubular epithelial cells, specifically claudin-16, -19 , and -14 [13].

\section{Claudins}

Claudins $(C L D N)$ are small tetraspan proteins (MW: $20-28 \mathrm{kDa}$ ) composing a family with at least 26 members. They are key components in the formation of the tight junction barrier and responsible for regulated paracellular ion flux [13]. In the TAL, paracellular $\mathrm{Mg}^{2+}$ absorption is facilitated by the combined effect of claudin-16 (paracellin-1) and claudin-19, and is inhibited by claudin-14 [14-17] (Fig. 2). Such arrangements represent a regulatory mechanism for controlled $\mathrm{Mg}^{2+}$ absorption. Studies have shown that the basolateral calcium-sensing receptor (CaSR), when activated, increases the expression of claudin-14, preventing excess $\mathrm{Mg}^{2+} / \mathrm{Ca}^{2+}$ absorption, responding to changes of the extracellular $\mathrm{Ca}^{2+}$ or $\mathrm{Mg}^{2+}$ concentration (detailed below). 


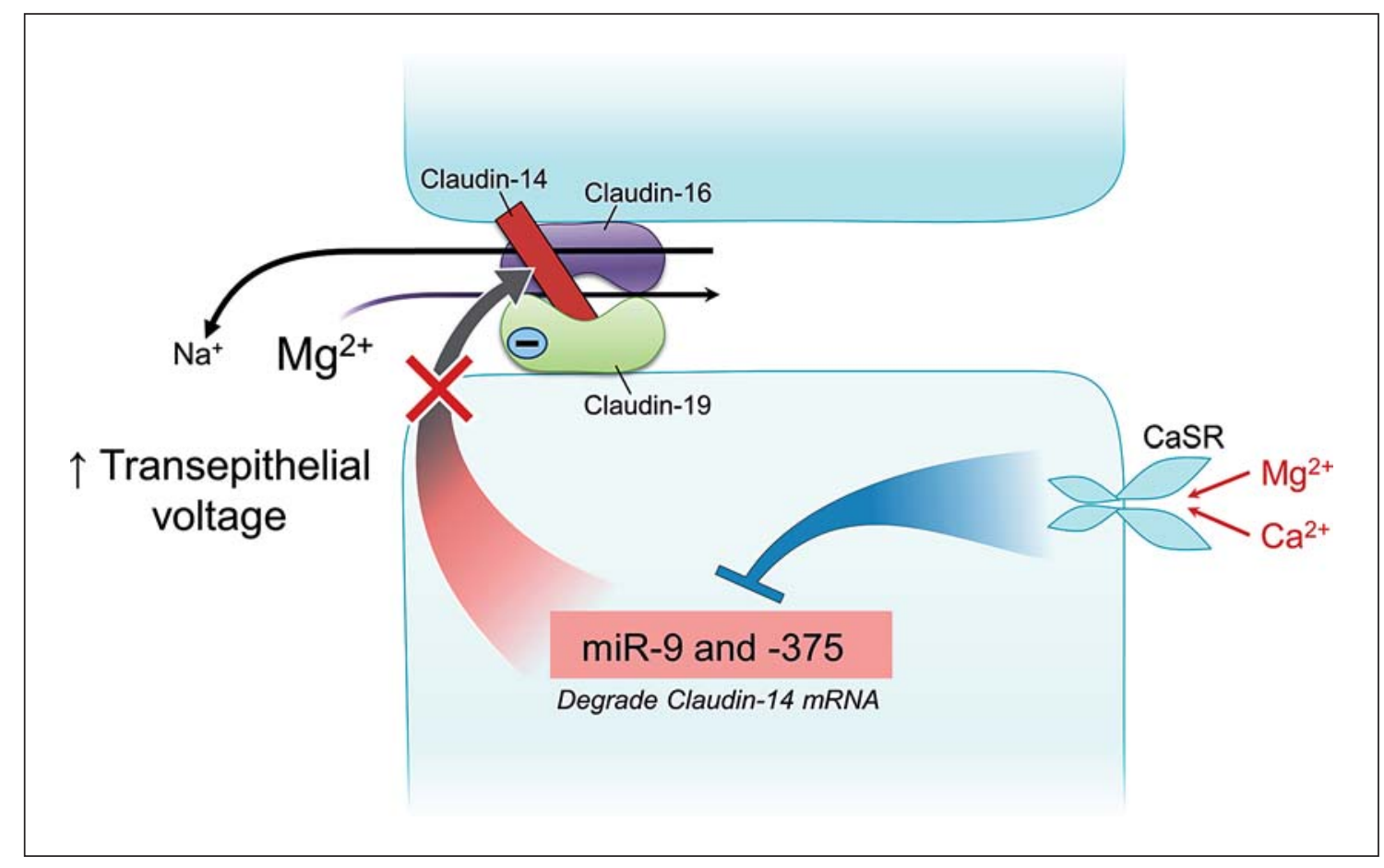

Fig. 3. Regulated paracellular $\mathrm{Mg}^{2+}$ absorption in the thick ascending limb of Henle (TAL). Claudin-16 by itself is highly permeable to $\mathrm{Na}^{+}$, and claudin-19 is impermeable to $\mathrm{Cl}^{-}$. Claudin-14 deters the sodium channel permeability of claudin $-16 . \mathrm{Na}^{+}$backleaks into the distal part of the TAL and helps in maintaining a positive luminal voltage. Blockage of this action of claudin-14 compromises the positive luminal voltage and diminishes the driving force for $\mathrm{Mg}^{2+}$ absorption. The deterrence of $\mathrm{Cl}^{-}$passage by claudin-19 cre-

In the last two decades, studies have elucidated underlying mechanisms in more detail. Claudin-16 and -19 colocalize in the TAL to form a cation complex [16]. Claudin-16 by itself is an $\mathrm{Na}^{+}$-permeable channel [18], and claudin-19 is a deterrent protein to the passage of $\mathrm{Cl}$ [16]. The $\mathrm{Cl}$ deterrence by claudin- 19 creates a negative microenvironment in the epithelial junction, creating an attraction for cation $\left(\mathrm{Mg}^{2+} / \mathrm{Ca}^{2+}\right)$ selection. At the end of the TAL, where the luminal $\mathrm{Na}^{+}$concentration is low and the basolateral $\mathrm{Na}^{+}$concentration relatively high (approx. $140 \mathrm{mM}$ ), through claudin-16 there is a backleak of $\mathrm{Na}^{+}$ from the basolateral aspect to the lumen. Such a backleak enhances the positive luminal voltage, fostering paracellular $\mathrm{Mg}^{2+}$ absorption (Fig. 3).

Recently, a claudin-10 (CLDN10) knockout mouse model has shown that claudin-10 [19], which is expressed almost exclusively in the tubular junction of the epithelia in the TAL, functions as an $\mathrm{Na}^{+}$-permeable protein. Deletion of claudin- 10 would deter $\mathrm{Na}^{+}$absorption and create ates a negative microdomain charge, creating a selective attraction to luminal $\mathrm{Mg}^{2+}$ and $\mathrm{Ca}^{2+}$. The basolateral calcium-sensing receptor (CaSR), when activated by an elevated concentration of $\mathrm{Mg}^{2+}$ or $\mathrm{Ca}^{2+}$, inhibits miR-9 and miR-375. The inhibition removes the interference of the microRNAs with claudin-14 translation, resulting in an increased claudin-14 translation and claudin-14-mediated inhibition of claudin-16, thus inhibiting $\mathrm{Mg}^{2+}$ and $\mathrm{Ca}^{2+}$ absorption.

an elevated luminal transepithelial voltage to increase $\mathrm{Mg}^{2+}$ absorption. Animals with claudin-10 deletion show elevated serum $\mathrm{Mg}^{2+}$ and $\mathrm{Ca}^{2+}$ concentrations and an impaired capacity of urine $\mathrm{Mg}^{2+}$ and $\mathrm{Ca}^{2+}$ excretion.

\section{Calcium-Sensing Receptor}

CaSR, a member of the $G$ protein-coupled receptor superfamily, is a $120-\mathrm{kDa}$ polypeptide containing seven transmembrane domains. CaSR is expressed abundantly in parathyroid glands and in kidney tubules. It also is expressed in multiple organ systems including the cardiovascular, gastrointestinal (specifically the ileum), airway, and central nervous systems [20]. Recent studies have provided compelling evidence that by recognizing and responding to miR-9 and miR-374 (small noncoding RNA molecules) [17], CaSR regulates the expression of claudin-14 in the TAL (Fig. 3), thereby regulating paracellular $\mathrm{Mg}^{2+}$ absorption. Recessive mutations in claudin-14 have been reported as a cause of nonsyndromic recessive deaf- 
Table 1. Dysmagnesemia related to salt-losing nephropathy

\begin{tabular}{lllll}
\hline & Inheritance & Mutant gene & $\begin{array}{l}\text { Transporter/ } \\
\text { protein }\end{array}$ & Key features \\
\hline Bartter syndrome I & AR & SLC12A1 & NKCC & $\begin{array}{l}\text { Regulated by CaSR, antenatal onset, hypokalemic, } \\
\text { hypercalciuric metabolic alkalosis }\end{array}$ \\
\hline Bartter syndrome II & AR & KCNJ1 & ROMK & Antenatal onset, can be hyperkalemic \\
\hline Bartter syndrome III & AR & ClC-Kb & ClC subunit B & $\begin{array}{l}\text { Variable childhood onset; milder form of Bartter } \\
\text { syndrome; variable, Gitelman-like presentation }\end{array}$ \\
\hline Bartter syndrome IV & AR & BSND & Barttin & $\begin{array}{l}\text { Sensorineural hearing defect, CKD/ESRD in second or } \\
\text { third decade of age }\end{array}$ \\
\hline Bartter syndrome V & AD & $\begin{array}{l}\text { CASR } \\
\text { (activating mutation) }\end{array}$ & CaSR & $\begin{array}{l}\text { Neonatal onset, can be variable; urine } \mathrm{Mg}^{2+} \text { and } \\
\text { Ca }{ }^{2+} \text { loss }\end{array}$ \\
\hline Gitelman syndrome & AR & SLC12A3 & NCC & $\begin{array}{l}\text { Childhood and adolescent onset, hypocalciuric } \\
\text { hypokalemic, metabolic alkalosis, urine Mg } \mathrm{Mg}^{2+} \text { loss }\end{array}$ \\
\hline
\end{tabular}

$\mathrm{AR}$, autosomal recessive; $\mathrm{AD}$, autosomal dominant; NKCC, $\mathrm{Na}-\mathrm{K}-\mathrm{Cl}$ cotransporter; CaSR, calcium-sensing receptor; $\mathrm{NCC}$, Na-Cl cotransporter; CKD, chronic kidney disease; ESRD, end-stage renal disease.

ness (DFNB29) [21] due to failure of ion balance in the organ of Corti [22]; there is no information as to any renal manifestations in affected individuals.

The importance of CaSR in the regulation of $\mathrm{Ca}^{2+}$ and $\mathrm{Mg}^{2+}$ has been demonstrated in mice models of $\mathrm{Casr}^{+/-}$ and $\mathrm{Casr}^{-/-}$mutations. The mutant mice phenocopy the manifestations of humans with familial hypocalciuric hypercalcemia $(\mathrm{FHH})$ and neonatal severe hyperparathyroidism (NSHPT). Consistently, the extracellular $\mathrm{Mg}^{2+}$ concentration is moderately elevated in $\mathrm{Casr}^{+/-}$mice, and more severely elevated in $\mathrm{Casr}^{-/-}$mice [23].

\section{Additional Transporters}

NKCC, ROMK, ClC-Kb, and barttin all contribute to a positive transepithelial voltage, favoring $\mathrm{Mg}^{2+}$ absorption. ROMK, ClC-Kb, and barttin cross the boundary of TAL and are expressed in the distal convoluted tubule (DCT). They have been described in detail in the context of salt-losing nephropathy (Table 1) [24-29].

\section{Dysmagnesemia due to Ion Channel/Transporter Mutations in the TAL}

\section{Hypercalciuria and Nephrocalcinosis}

CLDN16 and CLDN19 mutations are responsible for familial hypomagnesemia with hypercalciuria and nephrocalcinosis (FHHNC) $[14,15]$. FHHNC was initially re- ported in 1997 by Walder et al. [30] in three consanguineous Bedouin kindreds from Israel. CLDN16 mutations were found to be causative. Affected individuals exhibit severe and symptomatic hypomagnesemia in the range of 0.1-0.4 mM, hypercalciuria, and a nephrocalcinosis onset at the age of 2-8 weeks after birth. The symptoms include polyuria/polydipsia, muscular tetany, seizures, nephrolithiasis, and progressive loss of kidney function. Renal failure develops mostly in childhood or in adolescence [31]. In 2006, Konrad et al. [15] reported initial cases of FHHNC due to CLDN19 mutation - but without CLDN16 mutation - in Swiss and Spanish families, with nearly identical presentations. Patients with CLDN19 mutations additionally show ocular abnormalities. Recent studies have shown that both CLDN16 and CLDN19 mutations can give rise to abnormal enamel formations [32, 33].

More information is emerging on the spectrum of mutations, primarily in CLDN16, since approximately 46 mutations have been described to date, as well as the genotype-phenotype correlations. In a study on 25 families with FHHNC in Germany and Eastern European countries, a founder mutation $(\mathrm{L} 151 \mathrm{~F})$ in the first extracellular loop of claudin- 16 has been identified as being present in about $50 \%$ of mutant alleles [31]. Patients with loss-offunction mutations in both alleles in the CLDN16 gene tend to have an early onset of renal failure, whereas those harboring at least one mutant allele with some residual function seem protected from the rapid loss of renal func- 
tion [34]. Interestingly, a novel homozygous CLDN16 mutation (T233R) has been identified in two families with self-limiting childhood hypercalciuria. The hypercalciuria decreased with age and was not associated with declined renal function. The T233R mutation is the first mutation to be identified in the cytosolic tail of claudin-16, and is predicted to result in an ineffective PDZ domain-binding motif. This inactivation abolishes the association with the tight junction scaffolding protein $\mathrm{ZO}-1$, with subsequent accumulation of the mutant claudin-16 protein in lysosomes [35]. The underlying mechanism for such a mild phenotype in patients with this mutation is unknown. Much less is known about the genotype-phenotype correlations in CLDN19 mutations. Indeed, to date 14 mutations have been described, and no correlation between CLDN19 mutations and the rate of renal functional deterioration has been uncovered $[15,33,36]$.

\section{Autosomal Dominant Hypocalcemia and FHH}

CASR mutations cause a spectrum of phenotypes. Gain-of-function mutations are causative of autosomal dominant hypocalcemia (ADH). Loss-of-function mutations cause autosomal dominant FHH and autosomal recessive (homozygous or compound heterozygous mutations) NSHPT. Patients with gain-of-function CASR mutations develop varying degrees of hypocalcemia and hypomagnesemia from a stable and often mild form of $\mathrm{ADH}$ to a severe form of Bartter syndrome type V (Table 1). Opposite abnormalities of hypercalcemia and hypermagnesemia occur in patients with loss-of-function mutations. Most FHH patients are clinically asymptomatic and exhibit mild hypercalcemia and often hypermagnesemia, while NSHPT patients are characterized by severe hypercalcemia and typically die within 1 year after birth if parathyroidectomy is not provided [37].

Considerable clinical heterogeneity has been observed among patients with heterozygous CASR mutations. A small number of affected patients develop neonatal hyperparathyroidism associated with mild-to-moderate hypercalcemia during infancy. It was formerly assumed that a dominant negative effect and/or paternal inheritance could have modified the clinical presentation. Recent functional studies, however, have found no evidence for either effect [38], suggesting that other environmental or epigenetic factors yet to be identified might have played a role in the various disease presentations. Over 230 CASR mutations have been described, and several mutational hot spots and genotype-phenotype correlations of some degree have been demonstrated. For instance, functional studies of several mutations have shown that mutations in
C131W and A843E preferentially alter the $\mathrm{Ca}^{2+}$ response curve, differing from other CASR mutations (IEK47N and $\mathrm{P} 221 \mathrm{~L})$ without clinical features of urine $\mathrm{Mg}^{2+}$ wasting and hypomagnesemia [39]. More comprehensive information regarding CASR mutations and clinical manifestations have recently been comprehensively reviewed [40].

\section{Magnesium Absorption in the DCT}

The last approximately $10 \%$ of $\mathrm{Mg}^{2+}$ are absorbed in the DCT. $\mathrm{Mg}^{2+}$ absorption in this tubular section is transcellular instead of paracellular. The $\mathrm{Mg}^{2+}$ absorption is tightly regulated through multitudes of channels and transporter proteins. The more stringent regulation is justly called for, since this is the last part of the renal tubules with the capacity for absorbing luminal $\mathrm{Mg}^{2+}$. It fine-tunes and determines the final amount of urine $\mathrm{Mg}^{2+}$ excretion. The chemical gradient of $\mathrm{Mg}^{2+}$ in this section is small (luminal $\mathrm{Mg}^{2+}$ concentration: $0.2-0.7 \mathrm{mM}$; intracellular free $\mathrm{Mg}^{2+}$ : approx. 0.5-1.2 mM). Thus, a positive transapical membrane voltage gradient becomes critical for $\mathrm{Mg}^{2+}$ entry. All known regulatory pathways converge onto influencing the transapical membrane voltage, the principle driving force for $\mathrm{Mg}^{2+}$ entry into the DCT cells via TRPM6 (Fig. 4). The function and regulation of some transporters, e.g., SLC41A and CNNM2, have yet to be fully elucidated.

\section{TRPM6}

Two groups independently identified TRPM6 as the causative gene in hypomagnesemia with secondary hypocalcemia (HSH) in 2002 [41, 42]. TRPM6 is a $234-\mathrm{kDa}$ membrane protein with both its $\mathrm{N}$ - and its $\mathrm{C}$-termini residing in the cytosol. It has six transmembrane domains with a channel function between transmembrane domains 5 and 6 . It has an approximately 5 -fold higher affinity for $\mathrm{Mg}^{2+}$ than for $\mathrm{Ca}^{2+}$ [43]. Accordingly, patch clamp analysis showed that TRPM6 is an $\mathrm{Mg}^{2+}$ - and Capermeable cation channel preferentially transporting $\mathrm{Mg}^{2+}$ [43]. TRPM6 proteins form homotetrameric functional complexes as well as heterotetrameric complexes with TRPM7, the closest homolog of TRPM6 [44]. Both TRPM7-dependent and TRPM7-independent TRPM6 activity have been reported $[45,46]$.

TRPM6 contains multiple interacting regions. For instance, around channel areas, there is a TRP box that interacts with $\mathrm{PIP}_{2}$. Immediately downstream of the channel domain there is a coiled-coiled region that is believed to form dimers with other TRPM monomers. Insulin can
90

Kidney Dis 2017;3:85-97 DOI: $10.1159 / 000477730$
Li/Sun/Chen/Xu/Wang/Qian 


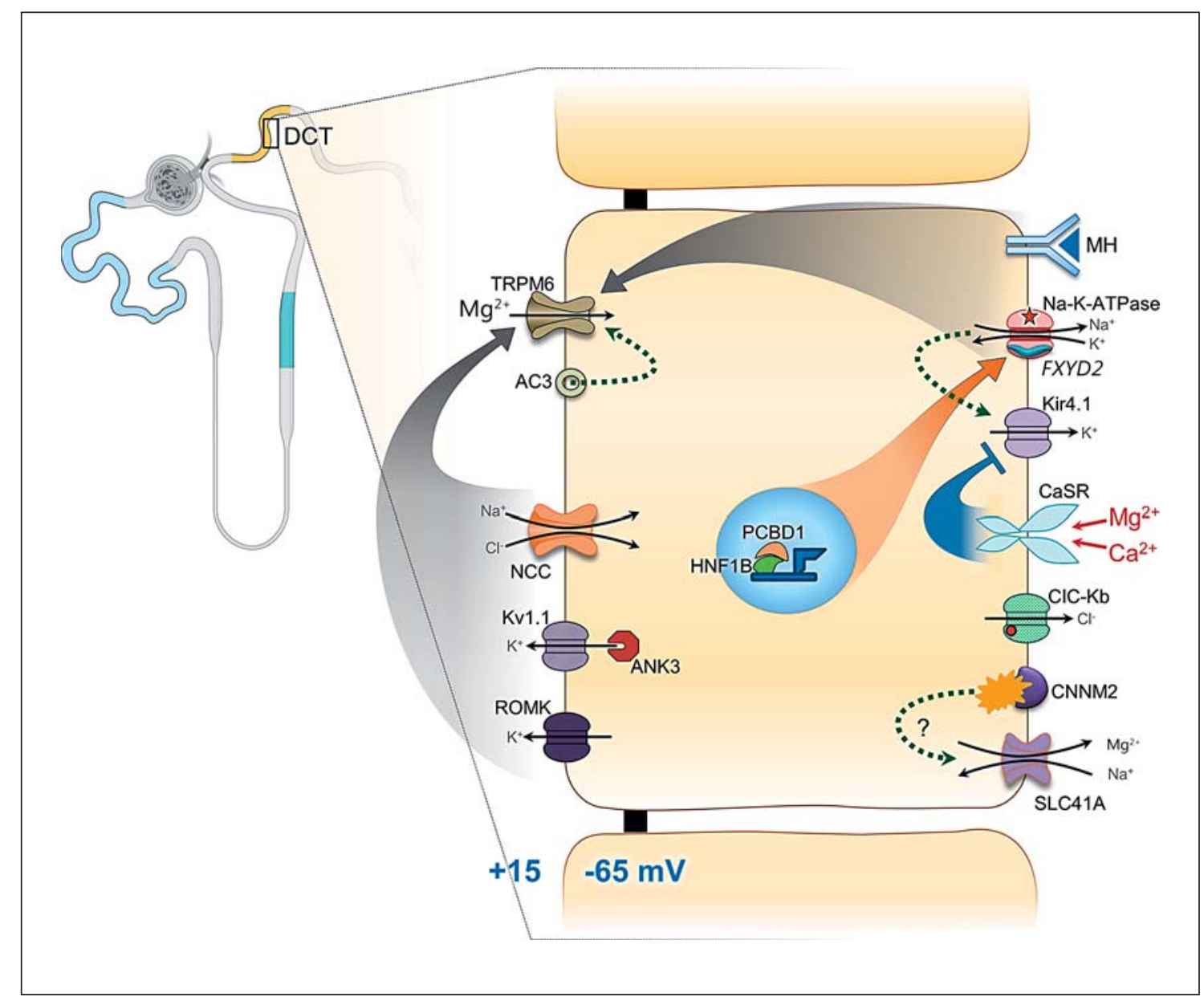

Fig. 4. Schematic presentation of magnesium regulation in the distal convoluted tubule. TRPM6 is the major channel for $\mathrm{Mg}^{2+} \mathrm{ab}-$ sorption in the distal convoluted tubule. The driving force for TRPM6-mediated $\mathrm{Mg}^{2+}$ intake is a positive apical membrane potential gradient. Na-K-ATPase is critical in the establishment of the transapical membrane gradient. PCBD1 and HNF1B are transcription factors promoting the expression of the $\gamma$-subunit of the Na-K-ATPase, encoded by FXYD2. Mutations in HNF1B and $P C B D 1$ interfere with transcriptional expression of the $\gamma$-subunit, thus leading to an insufficient transapical membrane potential and diminishing $\mathrm{Mg}^{2+}$ absorption via TRPM6. Channels important for the establishment of the apical membrane potential include trans-

react in the Ser-Thr-rich region upstream adjacent to the kinase domain. In the $\mathrm{C}$ terminus, there is an a-kinase domain that plays a regulatory role in response to RACK1 and REA. These regions are all targets of potential signaling interactions $[47,48]$. Thus, it comes as no surprise that TRPM6 can be activated by a number of signals including EGF, insulin, estrogen, purinergic signaling, dietary $\mathrm{Mg}^{2+}$ intake, and acid-base alterations. Recent studies have shown that plasma membrane TRPM6 expres- porters for $\mathrm{K}^{+}$excretion apically, $\mathrm{K}_{\mathrm{v}} 1.1$, and ROMK. Calciumsensing receptor (CaSR) inhibits basolateral $\mathrm{K}^{+}$exit via $\mathrm{K}_{\mathrm{ir}} 4.1$. Reduced $\mathrm{K}^{+}$recycling via $\mathrm{K}_{\mathrm{ir}} 4.1$ interferes with $\mathrm{Na}-\mathrm{K}$-ATPase function. $\mathrm{ClC}-\mathrm{Kb}$ is a basolateral $\mathrm{Cl}^{-}$exit channel. Its mutation and the mutation of its subunit barttin could both cause defects in $\mathrm{Cl}^{-}$exit in association with $\mathrm{Na}-\mathrm{Cl}$ cotransporter (NCC) function and the apical membrane potential. CNNM2 is a basolateral $\mathrm{Mg}^{2+}{ }_{-} \mathrm{Na}^{+}$exchanger which may function as a cytosolic $\mathrm{Mg}^{2+}$ sensor. SLC41A encodes an $\mathrm{Mg}^{2+}$ exit channel. The regulation(s) and physiological function(s) of the channels of CNNM2 and SLC41A are yet to be elucidated. $\mathrm{MH}$, magnesiotropic hormones (including EGF and insulin). 


\section{Pro-EGF/EGF and EFG Receptor}

Pro-EGF is expressed in the renal epithelia, primarily in the DCT $[50,51]$. Pro-EGF is proteolytically cleaved, and functional EGF is released. The released EGF activates EGF receptor that is expressed at the basolateral aspect of the renal epithelial cells [52]. Receptor activation triggers a signaling cascade involving Src kinase and Rac1, leading to increased trafficking of TRPM6 from intracellular vesicles to the apical membrane to mediate $\mathrm{Mg}^{2+}$ absorption [53].

\section{Gamma-Subunit of Na-K-ATPase}

The $\gamma$-subunit of Na-K-ATPase, encoded by FXYD2, is critical for the pump function, as it stabilizes the a-subunit of this pump [54] and increases the pump's affinity for ATP while reducing its affinity for $\mathrm{Na}^{+}$and $\mathrm{K}^{+}$. In the kidney, two splice forms of FXYD2 genes are expressed: FXYD2a, expressed primarily in the TAL and proximal tubules, and FXYD2b, expressed exclusively in the basolateral membrane of the DCT and collecting duct [55]. A mutation in FXYD2 causes misrouting of the mutant $\gamma$-subunit and fails to join the $\alpha$ - and $\beta$-subunits to form a complete and fully functional $\mathrm{Na}-\mathrm{K}$-ATPase [56]. The impairment of Na-K-ATPase function diminishes the driving force for apical NCC activity and compromises apical membrane voltage generation (partial depolarization of the cell), reducing the driving force for TRPM6-mediated $\mathrm{Mg}^{2+}$ entry. Reduced NCC activity also compromises TRPM6 activation associated with AC3/cAMP/PKA signaling [49].

\section{HNF1B and PCBD1}

HNF1B (hepatocyte nuclear factor 1 homeobox B) and PCBD1 (pterin-4a-carbinolamine dehydratase/ dimerization cofactor of hepatocyte nuclear factor 1 homeobox A) are the two known transcriptional regulatory factors for FXYD2 expression, especially in the distal tubules $[57,58]$. HNF1B is involved in organogenesis and the formation of tubular structures in the liver, pancreas, lung, and kidney, and its expression seems restricted to epithelial cells $[59,60]$. It has also been shown to transcriptionally activate $P K H D 1$, the gene which, when mutated, causes autosomal recessive cystic kidney disease [61]. Indeed, mutations in $H N F 1 B$ are emerging as the most frequent monogenic cause of developmental renal abnormalities [62]. PCBD1 is a dimerization cofactor for HNF1B in the nucleus [63, 64], as well as a cytosolic enzyme involved in the regeneration of tetrahydrobiopterin $\left(\mathrm{BH}_{4}\right)[65,66]$. Gene expression studies combined with immunohistochemical analyses of the kidney have shown that $P c b d 1$ is highly expressed in the DCT, where $P c b d 1$ transcript levels are upregulated by a low- $\mathrm{Mg}^{2+}$ diet $[58,67]$. PCBD1 increases HNF1B-induced FXYD2 transcription by $50 \%$ [58]. Mutant PCBD1 proteins were not capable of increasing FXYD2 transcription [58].

\section{KCNJ10}

$\mathrm{K}_{\mathrm{ir}} 4.1$ (potassium voltage-gated channel subfamily J member 10), encoded by KCNJ10, is expressed in the basolateral membrane of the DCT $[68,69]$. $\mathrm{K}_{\mathrm{ir}} 4.1$ mutation interferes with basolateral $\mathrm{K}^{+}$recycling, compromising $\mathrm{Na}-\mathrm{K}-\mathrm{ATPase}$ function and generation of the apical membrane potential. Convincing evidence has shown that CaSR, coexpressed in the same region, inhibits cell surface expression of $\mathrm{K}_{\mathrm{ir}} 4.1$ [70] via a mechanism dependent on $\mathrm{G}_{\mathrm{q}}$ and caveolin-1 [70, 71]. Reduced Na-KATPase activity due to $K_{\text {ir }} 4.1$ mutations causes a reduced apical NCC activity and apical membrane voltage, the major driving force for $\mathrm{Mg}^{2+}$ influx [72]. Importantly, CaSR is able to modulate $\mathrm{K}_{\mathrm{ir}} 4.1$-mediated potassium extrusion in response to the physiological range of the extracellular $\mathrm{Ca}^{2+}$ concentration $\left(\mathrm{EC}_{50} \mathrm{Ca}^{2+}\right.$ of $1.0 \mathrm{mM}$ ) [70]. Thus, through CaSR, $\mathrm{K}_{\text {ir }} 4.1$ regulates the distal nephron $\mathrm{NaCl}$ transport and apical membrane potential physiologically. Interestingly, in contradiction to classic teaching, no measurable CaSR-mediated ROMK inhibition could be demonstrated [70].

\section{KCNA1}

$\mathrm{K}_{\mathrm{v}} 1.1$ (potassium voltage-gated channel subfamily A member 1), encoded by KCNA1 [73], is an apical membrane $\mathrm{K}^{+}$channel contributing to the sustained transapical membrane voltage by extruding $\mathrm{K}^{+}$into the lumen. A mutation in $\mathrm{K}_{\mathrm{v}} 1.1$ was identified as a causative factor for isolated autosomal dominant hypomagnesemia due to renal $\mathrm{Mg}^{2+}$ wasting [73]. A recent study by San-Cristobal et al. [74] showed that the function of $\mathrm{K}_{\mathrm{v}} 1.1 \mathrm{can}$ be regulated by ankyrin-3 (ANK3), a member of adaptor proteins that link the cytoskeletal network to the cytoplasmic domain of plasma membrane proteins [75]. Mice on a high- $\mathrm{Mg}^{2+}$ diet have been shown to double their fractional urine $\mathrm{Mg}^{2+}$ excretion, associated with a 1.8 -fold increase in renal ANK3 expression. Using the carboxy terminal domain of $\mathrm{K}_{\mathrm{v}} 1.1$ to screen murine kidney lysates revealed that $\mathrm{K}_{\mathrm{v}} 1.1$ function can be inhibited by ANK3 . Biophysical studies have shown that ANK3 is able to functionally block the channel opening of $K_{v} 1.1$ without affecting its plasma membrane expression. Thus, $\mathrm{K}_{\mathrm{v}} 1.1$ is involved in establishing a positive and favorable electrical 
apical membrane gradient to drive $\mathrm{Mg}^{2+}$ entry through TRPM6 in the epithelial cells of the DCT.

Notably, the ANK3-binding motif is not present in the $\mathrm{K}_{\mathrm{v}} 1.1$ channel. Whether ANK3 binds the $\mathrm{K}_{\mathrm{v}} 1.1$ channel directly or through other proteins in a macromolecular complex is currently not known. Nonetheless, the data clearly demonstrate a role for ANK3 in regulating the biophysical properties of $\mathrm{K}_{\mathrm{v}} 1.1$, contributing to a physiologically relevant $\mathrm{Mg}^{2+}$ regulatory pathway.

\section{CNNM2 and SLC41A3}

The exact mechanism of basolateral $\mathrm{Mg}^{2+}$ efflux from the renal tubular cells is currently unknown. Studies have suggested that SLC41A3 $[76,77]$ and cyclin M2 (CNNM2) [78] may act as $\mathrm{Mg}^{2+}$ efflux channels. CNNM2 is also expressed in the basolateral membrane of the TAL [78]. CNNM2 contains two highly conserved CBS (cystathionine- $\beta$-synthase) domains, critical for dimerization with other transporters and also for the $\mathrm{Mg}^{2+}$-dependent gating of the magnesium transporter E channel [79], a homolog of the SLC41 family of transporters [80]. Protein topology and homology modeling of a conserved CBS domain, however, suggest that CNNM2 might function as a cytoplasmic $\mathrm{Mg}^{2+}$ sensor [81-83]. The mechanism regulating the functions of CNNM2 and SLC41A has yet to be fully elucidated.

\section{Other Transporters Affecting $\mathrm{Mg}^{2+}$ Homeostasis}

Mutations in the genes encoding NCC, ROMK, ClC$\mathrm{Kb}$, and barttin (a subunit of $\mathrm{ClC}-\mathrm{Kb}$ ) have been characterized in more detail under the category of salt-losing nephropathies [84-90] (Table 1).

\section{Dysmagnesemia due to Transporter/Protein Mutations in the DCT}

\section{Hypomagnesemia with Secondary Hypocalcemia}

TRPM6 mutations are responsible for $\mathrm{HSH}$, also known as primary intestinal hypomagnesemia. HSH patients typically present during the first few months of life with neurological symptoms of tetany and seizures associated with profound hypomagnesemia and secondary hypocalcemia due to parathyroid failure. $\mathrm{HSH}$ is associated with the most severe hypomagnesemia among all genetic forms of channelopathy, in the range of $0.05-0.20 \mathrm{mM}$ in a recent study [48], due to the dual defects in gastrointestinal and renal $\mathrm{Mg}^{2+}$ absorption. To date, fewer than 50 unique mutations in TRPM6 have been recorded [48]. Most of the mutations are predicted to give rise to a premature termi-

Genetics of $\mathrm{Mg}^{2+}$ Disorders nation of TRPM6 in approximately $85 \%$ of the mutations tested. The remaining mutations include missense mutations and mutations affecting the TRPM gating property or interfering with its plasma membrane trafficking. Thus far, most TRPM6 mutant products tested in vitro in cellular systems have shown a dramatic decrease in channel currents, with the exception of the Q1663R variant, which functions almost the same way as the wild-type TRPM6 [48]. Overall, there has been no clear pattern of genotypephenotype association. It should be noted that in a number of cases, the diagnosis and consequent $\mathrm{Mg}^{2+}$ administration were delayed because the $\mathrm{Mg}^{2+}$ level was not measured on initial presentation, and the patients suffered from repeated convulsions leading to permanent brain damage and mental retardation [30, 41, 42].

\section{Isolated Recessive Hypomagnesemia}

Isolated recessive hypomagnesemia is an autosomal recessive disorder [91] caused by a mutation in the EGF gene, c.3209C $>$ T (p.Pro1070Leu), causing a defect in the basolateral trafficking of pro-EGF, in turn leading to a defect in soluble EGF elaboration and in EGF-mediated apical TRPM6 expression [50]. Affected individuals present with seizures during infancy and mental retardation due to severe hypomagnesemia. $\mathrm{Ca}^{2+}$ derangement is typically spared [91]. Similarly, cetuximab, an EGFR antibody used as an anticancer agent, has been associated with severe hypomagnesemia due to lack of EGF receptor-mediated TRPM6 trafficking to the apical membrane and lack of $\mathrm{Mg}^{2+}$ absorption through TRPM6 $[92,93]$.

\section{EAST Syndrome and SeSAME Syndrome}

Mutations in the KCNJ10 gene, encoding $\mathrm{K}_{\text {ir }} 4.1$, were shown to cause a syndrome named EAST (epilepsy, ataxia, sensorineural deafness, and tubulopathy) and SeSAME (seizures, sensorineural deafness, ataxia, mental retardation, and electrolyte imbalance) by two independent groups $[69,94]$. The syndrome is characterized by seizures, sensorineural deafness, and ataxia, as well as by electrolyte alterations akin to those in Gitelman syndrome including salt wasting, hypokalemic metabolic alkalosis, and hypomagnesemia. The serum $\mathrm{Ca}^{2+}$ concentration, however, tends to be reduced $[69,94]$. Because mental retardation has not been a clinical feature, the term "EAST syndrome" seems appropriate and is used clinically. $\mathrm{K}_{\mathrm{ir}} 4.1$ mutations, by interfering with $\mathrm{Na}-\mathrm{K}$ ATPase activity, compromise apical $\mathrm{Na}^{+}$entry via the NCC channel, thus partially depolarizing the apical membrane and diminishing the favorable driving force for $\mathrm{Mg}^{2+}$ influx via the TRPM6 channels.

Kidney Dis 2017;3:85-97 DOI: $10.1159 / 000477730$ 


\section{Autosomal Dominant Hypomagnesemia}

$\mathrm{K}_{\mathrm{v}} 1.1$ is a Shaker-related voltage-gated $\mathrm{K}^{+}$channel encoded by KCNA1. Its mutation, c.763A $>\mathrm{G}$ (p.Asn255Asp), has been shown to cause autosomal dominant hypomagnesemia [73]. It is posited that the substitution of the highly conserved asparagine for aspartic acid renders the $K_{v} 1.1$ channel nonfunctional. The mutation was identified in a large Brazilian family. Of the 46 family members, 21 carried the mutation and were affected by severe hypomagnesemia. Affected individuals experience muscle cramps, tetanic episodes, muscle weakness, and myokymia [73]. Remarkably, $\mathrm{K}_{\mathrm{v}} 1.1$ mutations have been identified previously and have been associated with episodic ataxia without $\mathrm{Mg}^{2+}$ alteration [95]. The previously described mutations are adjacent to the mutations that are responsible for hypomagnesemia. It is hypothesized that replacement of a neutral amino acid (asparagine) with an acidic (aspartic) acid - which alters the structure of $\mathrm{K}_{\mathrm{v}} 1.1$, resulting in a defect in apical $\mathrm{K}^{+}$efflux via $\mathrm{K}_{\mathrm{v}} 1.1$ - compromises the generation of the transapical membrane potential, leading to a defect in $\mathrm{Mg}^{2+}$ absorption.

\section{Isolated Dominant Hypomagnesemia}

To date, a total of 3 families with hypomagnesemia related to an FXYD2 mutation have been identified. These 3 families have the identical c.115G $>$ A (p.Gly41Arg) mutation. The first family reported with this mutation and hypomagnesemia was a Dutch family $[56,96,97]$. Recently, 2 additional families were identified, from Belgium and the Netherlands [98]. The affected individuals show hypomagnesemia and hypocalcemia. Some of them have polyuria and hypokalemia. All of the affected individuals complained of muscle cramps and generalized weakness. Kidney failure was reported in one of the probands. Interestingly, haplotype analyses suggest that the 3 families have a common founder, but genealogy failed to identify a common ancestor up to 1700 [98].

\section{Hypomagnesemia and Maturity-Onset Diabetes}

of the Young

Patients with dominant mutations in the $H N F 1 B$ gene or recessive mutations in the $P C B D 1$ gene can develop hypomagnesemia and maturity-onset diabetes of the young $[58,99]$. These clinical findings could be explained at the molecular level by the role of PCBD1 as a transcriptional coactivator of HNF1B. HNF1B mutations have also been associated with polycystic kidney disease and urogenital malformations, consistent with the role of HNF1B in transcriptional activation of PKHD1 [61] and organo- genesis $[59,60,62]$. Not all patients harboring these mutations, however, develop hypomagnesemia [58, 100]. Further studies are necessary to better understand the underlying genotype-phonotype relation.

\section{Dominant Hypomagnesemia due to CNNM2 Mutations}

Two unrelated families with dominant hypomagnesemia were found to carry two mutations in the CNNM2 gene $[78,101]$. One is the heterozygous deletion c.117delG (p.Ile40SerfsX15), and the other is the heterozygous missense mutation c.1703C $>\mathrm{T}$ (p.Thr568Ile). The deletion causes truncated proteins and the missense mutation causes a substitution of an amino acid for one of the two highly conserved CBS domains. Significant intrafamilial phenotypic variation was observed. In the family with the truncating mutation, the proband developed symptomatic hypomagnesemia at the age of 2 years, while his mother developed symptoms in her teenage years.

\section{Remaining Questions and Future Research}

Although our understanding of $\mathrm{Mg}^{2+}$ regulation, especially in the kidneys, has improved tremendously in the space of the last 20 years, a large number of questions remain. For instance, most of the $\mathrm{Mg}^{2+}$ transporter-mediated signaling pathways have not been fully elucidated; the underlying reasons for the large and complex variations in genotype and phenotype are unknown, as are the epigenetic factors and genetic modifiers that may influence the clinical phenotypes. Moreover, whether the other TAL-expressed claudins (i.e., claudin-10) perform a role in $\mathrm{Mg}^{2+}$ homeostasis is unclear. $\mathrm{Mg}^{2+}$ dysregulation in mitochondrial diseases has not been well characterized. Lastly, many proposed disease mechanisms are speculative (i.e., the pathophysiology of renal failure in FHHNC). That said, with emerging modern technologies - i.e., high-resolution microscopy and crystallography, which has resolved the crystal structures of claudin [102] and $\mathrm{Mg}^{2+}$ transporter proteins (Mrs2 and SLC41A) [79, 103-105], newer electrophysiology techniques, genome-wide association studies, next-generation sequencing technology, and analytical tools - it is foreseeable that, before long, more information on $\mathrm{Mg}^{2+}$ regulation and dysregulation will be revealed. Studies on genetic alterations would help us to manage the common clinical patients with dysmagnesemia.
$94 \quad$ Kidney Dis 2017;3:85-97
Li/Sun/Chen/Xu/Wang/Qian 


\section{Conclusion}

$\mathrm{Mg}^{2+}$ is a critical cation, inextricably intertwined with numerous cellular functions to maintain cell viability and tissue integrity. Dysmagnesemia and polymorphisms of genes related to $\mathrm{Mg}^{2+}$ regulation have been associated with a number of diseases including cancer, diabetes, nephrolithiasis, osteoporosis, and an array of neurologi$\mathrm{cal}$ abnormalities. The genetics of $\mathrm{Mg}^{2+}$ dysregulation are heterogeneous and complex. Although significant progress has been made, the quest for more details and for the remaining unknowns continues. These efforts are well justified, since understanding the underlying regulations and abnormalities will facilitate a better diagnosis, prevention, and management of nongenetic forms of dysmagnesemia which are common and can be associated with devastating consequences [2].

\section{Conflict of Interest Statement}

The authors have no competing interests.

\section{References}

1 Chan KH, Chacko SA, Song Y, et al: Genetic variations in magnesium-related ion channels may affect diabetes risk among African American and Hispanic American women. J Nutr 2015;145:418-424.

2 Cheungpasitporn W, Thongprayoon C, Qian Q: Dysmagnesemia in hospitalized patients: prevalence and prognostic importance. Mayo Clin Proc 2015;90:1001-1010.

3 Piskacek M, Zotova L, Zsurka G, et al: Conditional knockdown of hMRS2 results in loss of mitochondrial $\mathrm{Mg}^{2+}$ uptake and cell death. J Cell Mol Med 2009;13:693-700.

4 de Baaij JH, Hoenderop JG, Bindels RJ: Magnesium in man: implications for health and disease. Physiol Rev 2015;95:1-46.

5 Thorleifsson G, Holm H, Edvardsson V, et al: Sequence variants in the CLDN14 gene associate with kidney stones and bone mineral density. Nat Genet 2009;41:926-930.

6 Shen B, Sun L, Zheng H, et al: The association between single-nucleotide polymorphisms of TRPM7 gene and breast cancer in Han Population of Northeast China. Med Oncol 2014;31:51.

7 Lin JY, Chung SY, Lin MC, et al: Effects of magnesium sulfate on energy metabolites and glutamate in the cortex during focal cerebral ischemia and reperfusion in the gerbil monitored by a dual-probe microdialysis technique. Life Sci 2002;71:803-811.

8 Smith DA, Connick JH, Stone TW: Effect of changing extracellular levels of magnesium on spontaneous activity and glutamate release in the mouse neocortical slice. Br J Pharmacol 1989;97:475-482.

9 Pasina L, Zanotta D, Puricelli S, et al: Acute neurological symptoms secondary to hypomagnesemia induced by proton pump inhibitors: a case series. Eur J Clin Pharmacol 2016; 72:641-643.

10 Chardain A, Mesnage V, Alamowitch S, et al: Posterior reversible encephalopathy syndrome (PRES) and hypomagnesemia: a frequent association? Rev Neurol (Paris) 2016; 172:384-388.
11 Ebel H, Günther T: Magnesium metabolism: a review. J Clin Chem Clin Biochem 1980;18: 257-270.

12 Le Grimellec C: Micropuncture study along the proximal convoluted tubule. Electrolyte reabsorption in first convolutions. Pflugers Arch 1975;354:133-150.

13 Morita K, Furuse M, Fujimoto K, et al: Claudin multigene family encoding four-transmembrane domain protein components of tight junction strands. Proc Natl Acad Sci USA 1999;96:511-516.

14 Simon DB, Lu Y, Choate KA, et al: Paracellin-1, a renal tight junction protein required for paracellular $\mathrm{Mg}^{2+}$ resorption. Science 1999;285:103-106.

15 Konrad M, Schaller A, Seelow D, et al: Mutations in the tight-junction gene claudin 19 (CLDN19) are associated with renal magnesium wasting, renal failure, and severe ocular involvement. Am J Hum Genet 2006; 79:949957.

16 Hou J, Renigunta A, Konrad M, et al: Claudin-16 and claudin-19 interact and form a cation-selective tight junction complex. J Clin Invest 2008;118:619-628.

17 Gong Y, Renigunta V, Himmerkus N, et al: Claudin-14 regulates renal $\mathrm{Ca}^{++}$transport in response to CaSR signalling via a novel microRNA pathway. EMBO J 2012;31:19992012.

18 Hou J, Paul DL, Goodenough DA: Paracellin-1 and the modulation of ion selectivity of tight junctions. J Cell Sci 2005;118(pt 21): 5109-5118.

19 Breiderhoff T, Himmerkus N, Stuiver M, et al: Deletion of claudin-10 (Cldn10) in the thick ascending limb impairs paracellular sodium permeability and leads to hypermagnesemia and nephrocalcinosis. Proc Natl Acad Sci USA 2012;109:14241-14246.

20 Díaz-Soto G, Rocher A, García-Rodríguez C, et al: The calcium-sensing receptor in health and disease. Int Rev Cell Mol Biol 2016;327: 321-369.
21 Wilcox ER, Burton QL, Naz S, et al: Mutations in the gene encoding tight junction claudin-14 cause autosomal recessive deafness DFNB29. Cell 2001;104:165-172.

22 Kitajiri SI, Furuse M, Morita K, et al: Expression patterns of claudins, tight junction adhesion molecules, in the inner ear. Hear Res 2004; 187:25-34.

23 Ho C, Conner DA, Pollak MR, et al: A mouse model of human familial hypocalciuric hypercalcemia and neonatal severe hyperparathyroidism. Nat Genet 1995;11:389-394.

24 Simon DB, Karet FE, Hamdan JM, et al: Bartter's syndrome, hypokalaemic alkalosis with hypercalciuria, is caused by mutations in the $\mathrm{Na}-\mathrm{K}-2 \mathrm{Cl}$ cotransporter NKCC2. Nat Genet 1996;13:183-188.

25 Castrop H, Schiessl IM: Physiology and pathophysiology of the renal $\mathrm{Na}-\mathrm{K}-2 \mathrm{Cl} \mathrm{co}^{-}$ transporter (NKCC2). Am J Physiol Renal Physiol 2014;307:F991-F1002.

26 Finer G, Shalev H, Birk OS, et al: Transient neonatal hyperkalemia in the antenatal (ROMK defective) Bartter syndrome. J Pediatr 2003;142:318-323.

27 Simon DB, Bindra RS, Mansfield TA, et al: Mutations in the chloride channel gene, CLCNKB, cause Bartter's syndrome type III. Nat Genet 1997;17:171-178.

28 Birkenhäger R, Otto E, Schürmann MJ, et al: Mutation of BSND causes Bartter syndrome with sensorineural deafness and kidney failure. Nat Genet 2001;29:310-314.

29 Simon DB, Karet FE, Rodriguez-Soriano J, et al: Genetic heterogeneity of Bartter's syndrome revealed by mutations in the $\mathrm{K}^{+}$channel, ROMK. Nat Genet 1996;14:152-156.

30 Walder RY, Shalev H, Brennan TM, et al: Familial hypomagnesemia maps to chromosome 9q, not to the X chromosome: genetic linkage mapping and analysis of a balanced translocation breakpoint. Hum Mol Genet 1997;6:1491-1497. 
31 Weber S, Schneider L, Peters M, et al: Novel paracellin-1 mutations in 25 families with familial hypomagnesemia with hypercalciuria and nephrocalcinosis. J Am Soc Nephrol 2001;12:1872-1881.

32 Bardet C, Courson F, Wu Y, et al: Claudin-16 deficiency impairs tight junction function in ameloblasts, leading to abnormal enamel formation. J Bone Miner Res 2016;31:498-513.

33 Yamaguti PM, Neves FA, Hotton D, et al: Amelogenesis imperfecta in familial hypomagnesaemia and hypercalciuria with nephrocalcinosis caused by CLDN19 gene mutations. J Med Genet 2017;54:26-37.

34 Konrad M, Hou J, Weber S, et al: CLDN16 genotype predicts renal decline in familial hypomagnesemia with hypercalciuria and nephrocalcinosis. J Am Soc Nephrol 2008;19: 171-181.

35 Müller D, Kausalya PJ, Claverie-Martin F, et al: A novel claudin 16 mutation associated with childhood hypercalciuria abolishes binding to ZO-1 and results in lysosomal mistargeting. Am J Hum Genet 2003;73:1293-1301.

36 Godron A, Harambat J, Boccio V, et al: Familial hypomagnesemia with hypercalciuria and nephrocalcinosis: phenotype-genotype correlation and outcome in 32 patients with CLDN16 or CLDN19 mutations. Clin J Am Soc Nephrol 2012;7:801-809.

37 Blair JW, Carachi R: Neonatal primary hyperparathyroidism - a case report and review of the literature. Eur J Pediatr Surg 1991;1:110114.

38 Glaudo M, Letz S, Quinkler M, et al: Heterozygous inactivating CaSR mutations causing neonatal hyperparathyroidism: function, inheritance and phenotype. Eur J Endocrinol 2016;175:421-431.

39 Watanabe S, Fukumoto S, Chang H, et al: Association between activating mutations of calcium-sensing receptor and Bartter's syndrome. Lancet 2002;360:692-694.

40 Hannan FM, Babinsky VN, Thakker RV: Disorders of the calcium-sensing receptor and partner proteins: insights into the molecular basis of calcium homeostasis. J Mol Endocrinol 2016;57:R127-R142.

41 Walder RY, Landau D, Meyer P, et al: Mutation of TRPM6 causes familial hypomagnesemia with secondary hypocalcemia. Nat Genet 2002;31:171-174.

42 Schlingmann KP, Weber S, Peters M, et al: Hypomagnesemia with secondary hypocalcemia is caused by mutations in TRPM6, a new member of the TRPM gene family. Nat Genet 2002;31:166-170.

43 Voets T, Nilius B, Hoefs S, et al: TRPM6 forms the $\mathrm{Mg}^{2+}$ influx channel involved in intestinal and renal $\mathrm{Mg}^{2+}$ absorption. J Biol Chem 2004; 279:19-25.

44 Chubanov V, Waldegger S, Mederos y Schnitzler M, et al: Disruption of TRPM6/ TRPM7 complex formation by a mutation in the TRPM6 gene causes hypomagnesemia with secondary hypocalcemia. Proc Natl Acad Sci USA 2004;101:2894-2899.
45 Schmitz C, Dorovkov MV, Zhao X, et al: The channel kinases TRPM6 and TRPM7 are functionally nonredundant. J Biol Chem 2005;280:37763-37771.

46 Li M, Jiang J, Yue L: Functional characterization of homo- and heteromeric channel kinases TRPM6 and TRPM7. J Gen Physiol 2006;127:525-537.

47 Xie J, Sun B, Du J, et al: Phosphatidylinositol 4,5-bisphosphate $\left(\mathrm{PIP}_{2}\right)$ controls magnesium gatekeeper TRPM6 activity. Sci Rep 2011;1: 146.

48 Lainez S, Schlingmann KP, van der Wijst J, et al: New TRPM6 missense mutations linked to hypomagnesemia with secondary hypocalcemia. Eur J Hum Genet 2014;22:497-504.

49 Blanchard MG, Kittikulsuth W, Nair AV, et al: Regulation of $\mathrm{Mg}^{2+}$ reabsorption and transient receptor potential melastatin type 6 activity by cAMP signaling. J Am Soc Nephrol 2016;27:804-813.

50 Groenestege WM, Thébault S, van der Wijst $J$, et al: Impaired basolateral sorting of proEGF causes isolated recessive renal hypomagnesemia. J Clin Invest 2007;117:2260-2267.

51 Poulsen SS, Nexø E, Olsen PS, et al: Immunohistochemical localization of epidermal growth factor in rat and man. Histochemistry 1986;85:389-394.

52 Breyer MD, Redha R, Breyer JA: Segmental distribution of epidermal growth factor binding sites in rabbit nephron. Am J Physiol 1990; 259(pt 2):F553-F558.

53 Thebault S, Alexander RT, Tiel Groenestege WM, et al: EGF increases TRPM6 activity and surface expression. J Am Soc Nephrol 2009; 20:78-85.

54 Mishra NK, Peleg Y, Cirri E, et al: FXYD proteins stabilize Na,K-ATPase: amplification of specific phosphatidylserine-protein interactions. J Biol Chem 2011;286:9699-9712.

55 Arystarkhova E, Sweadner KJ: Splice variants of the gamma subunit (FXYD2) and their significance in regulation of the $\mathrm{Na}, \mathrm{K}-\mathrm{ATP}$ ase in kidney. J Bioenerg Biomembr 2005;37:381-386.

56 Meij IC, Koenderink JB, van Bokhoven H, et al: Dominant isolated renal magnesium loss is caused by misrouting of the $\mathrm{Na}^{+}, \mathrm{K}^{+}$-ATPase $\gamma$-subunit. Nat Genet 2000;26:265-266.

57 Ferrè S, Veenstra GJ, Bouwmeester R, et al: HNF-1B specifically regulates the transcription of the $\gamma$ a-subunit of the $\mathrm{Na}^{+} / \mathrm{K}^{+}$-ATPase. Biochem Biophys Res Commun 2011;404: 284-290.

58 Ferrè $\mathrm{S}$, de Baaij JH, Ferreira $\mathrm{P}$, et al: Mutations in PCBD1 cause hypomagnesemia and renal magnesium wasting. J Am Soc Nephrol 2014;25:574-586.

59 Coffinier C, Barra J, Babinet C, et al: Expression of the vHNF1/HNF1 $\beta$ homeoprotein gene during mouse organogenesis. Mech Dev 1999;89:211-213.

60 Kolatsi-Joannou M, Bingham C, Ellard S, et al: Hepatocyte nuclear factor- $1 \beta$ : a new kindred with renal cysts and diabetes and gene expression in normal human development. J Am Soc Nephrol 2001;12:2175-2180.
61 Hiesberger T, Bai Y, Shao X, et al: Mutation of hepatocyte nuclear factor- $1 \beta$ inhibits $P k h d 1$ gene expression and produces renal cysts in mice. J Clin Invest 2004;113:814-825.

62 Clissold RL, Hamilton AJ, Hattersley AT, et al: HNF1B-associated renal and extra-renal disease-an expanding clinical spectrum. Nat Rev Nephrol 2015;11:102-112.

63 Johnen G, Kaufman S: Studies on the enzymatic and transcriptional activity of the dimerization cofactor for hepatocyte nuclear factor 1. Proc Natl Acad Sci USA 1997;94: 13469-13474.

64 Sourdive DJ, Transy C, Garbay S, et al: The bifunctional $\mathrm{DCOH}$ protein binds to HNF1 independently of its 4- $\alpha$-carbinolamine dehydratase activity. Nucleic Acids Res 1997;25: 1476-1484.

65 Citron BA, Davis MD, Milstien S, et al: Identity of 4a-carbinolamine dehydratase, a component of the phenylalanine hydroxylation system, and $\mathrm{DCoH}$, a transregulator of homeodomain proteins. Proc Natl Acad Sci USA 1992;89:11891-11894.

66 Werner ER, Blau N, Thöny B: Tetrahydrobiopterin: biochemistry and pathophysiology. Biochem J 2011;438:397-414.

67 de Baaij JH, Groot Koerkamp MJ, Lavrijsen $\mathrm{M}$, et al: Elucidation of the distal convoluted tubule transcriptome identifies new candidate genes involved in renal $\mathrm{Mg}^{2+}$ handling. Am J Physiol Renal Physiol 2013;305:F1563F1573.

68 Reichold M, Zdebik AA, Lieberer E, et al: KCNJ10 gene mutations causing EAST syndrome (epilepsy, ataxia, sensorineural deafness, and tubulopathy) disrupt channel function. Proc Natl Acad Sci USA 2010;107: 14490-14495.

69 Bockenhauer D, Feather S, Stanescu HC, et al: Epilepsy, ataxia, sensorineural deafness, tubulopathy, and KCNJ10 mutations. N Engl J Med 2009;360:1960-1970.

70 Cha SK, Huang C, Ding Y, et al: Calciumsensing receptor decreases cell surface expression of the inwardly rectifying $\mathrm{K}^{+}$channel Kir4.1. J Biol Chem 2011;286:1828-1835.

71 Huang C, Sindic A, Hill CE, et al: Interaction of the $\mathrm{Ca}^{2+}$-sensing receptor with the inwardly rectifying potassium channels Kir4.1 and Kir4.2 results in inhibition of channel function. Am J Physiol Renal Physiol 2007; 292:F1073-F1081.

72 Sala-Rabanal M, Kucheryavykh LY, Skatchkov SN, et al: Molecular mechanisms of EAST/SeSAME syndrome mutations in Kir4.1 (KCNJ10). J Biol Chem 2010;285: 36040-36048.

73 Glaudemans B, van der Wijst J, Scola RH, et al: A missense mutation in the Kv1.1 voltagegated potassium channel-encoding gene KCNA1 is linked to human autosomal dominant hypomagnesemia. J Clin Invest 2009; 119:936-942. 
74 San-Cristobal P, Lainez S, Dimke H, et al: Ankyrin-3 is a novel binding partner of the voltage-gated potassium channel Kv1.1 implicated in renal magnesium handling. Kidney Int 2014;85:94-102.

75 Bennett V: Ankyrins. Adaptors between diverse plasma membrane proteins and the cytoplasm. J Biol Chem 1992;267:8703-8706.

76 Quamme GA: Molecular identification of ancient and modern mammalian magnesium transporters. Am J Physiol Cell Physiol 2010; 298:C407-C429.

77 Kolisek M, Nestler A, Vormann J, et al: $\mathrm{Hu}-$ man gene SLC41A1 encodes for the $\mathrm{Na}^{+} / \mathrm{Mg}^{2+}$ exchanger. Am J Physiol Cell Physiol 2012; 302:C318-C326.

78 Stuiver M, Lainez S, Will C, et al: CNNM2, encoding a basolateral protein required for renal $\mathrm{Mg}^{2+}$ handling, is mutated in dominant hypomagnesemia. Am J Hum Genet 2011;88: 333-343.

79 Hattori M, Iwase N, Furuya N, et al: $\mathrm{Mg}^{2+}$ dependent gating of bacterial MgtE channel underlies $\mathrm{Mg}^{2+}$ homeostasis. EMBO J 2009; 28:3602-3612.

80 Sahni J, Scharenberg AM: The SLC41 family of MgtE-like magnesium transporters. Mol Aspects Med 2013;34:620-628.

81 de Baaij JH, Stuiver M, Meij IC, et al: Membrane topology and intracellular processing of cyclin M2 (CNNM2). J Biol Chem 2012;287: 13644-13655.

82 Corral-Rodríguez MA, Stuiver M, AbascalPalacios G, et al: Nucleotide binding triggers a conformational change of the CBS module of the magnesium transporter CNNM2 from a twisted towards a flat structure. Biochem J 2014;464:23-34.

83 Salminen A, Anashkin VA, Lahti M, et al: Cystathionine $\beta$-synthase (CBS) domains confer multiple forms of $\mathrm{Mg}^{2+}$-dependent cooperativity to family II pyrophosphatases. J Biol Chem 2014;289:22865-22876.

84 Seyberth HW: An improved terminology and classification of Bartter-like syndromes. Nat Clin Pract Nephrol 2008;4:560-567.
85 Alfandary H, Landau D: Future considerations based on the information from Barrter's [sic!] and Gitelman's syndromes. Curr Opin Nephrol Hypertens 2017;26:9-13.

86 Simon DB, Nelson-Williams C, Bia MJ, et al: Gitelman's variant of Bartter's syndrome, inherited hypokalaemic alkalosis, is caused by mutations in the thiazide-sensitive $\mathrm{Na}-\mathrm{Cl}$ cotransporter. Nat Genet 1996;12:24-30.

87 Balavoine AS, Bataille P, Vanhille P, et al: Phenotype-genotype correlation and follow-up in adult patients with hypokalaemia of renal origin suggesting Gitelman syndrome. Eur J Endocrinol 2011;165:665-673.

88 Berry MR, Robinson C, Karet Frankl FE: Unexpected clinical sequelae of Gitelman syndrome: hypertension in adulthood is common and females have higher potassium requirements. Nephrol Dial Transplant 2013; 28:1533-1542.

89 Glaudemans B, Yntema HG, San-Cristobal P, et al: Novel NCC mutants and functional analysis in a new cohort of patients with Gitelman syndrome. Eur J Hum Genet 2012;20: 263-270.

90 Moes AD, van der Lubbe N, Zietse R, et al: The sodium chloride cotransporter SLC12A3: new roles in sodium, potassium, and blood pressure regulation. Pflugers Arch 2014;466: $107-118$.

91 Geven WB, Monnens LA, Willems JL, et al: Isolated autosomal recessive renal magnesium loss in two sisters. Clin Genet 1987;32: 398-402.

92 Schrag D, Chung KY, Flombaum C, et al: Cetuximab therapy and symptomatic hypomagnesemia. J Natl Cancer Inst 2005;97:12211224.

93 Tejpar S, Piessevaux H, Claes K, et al: Magnesium wasting associated with epidermalgrowth-factor receptor-targeting antibodies in colorectal cancer: a prospective study. Lancet Oncol 2007;8:387-394.

94 Scholl UI, Choi M, Liu T, et al: Seizures, sensorineural deafness, ataxia, mental retardation, and electrolyte imbalance (SeSAME syndrome) caused by mutations in KCNJ10. Proc Natl Acad Sci USA 2009;106:5842-5847.
95 Imbrici P, D’Adamo MC, Grottesi A, et al: Episodic ataxia type 1 mutations affect fast inactivation of $\mathrm{K}^{+}$channels by a reduction in either subunit surface expression or affinity for inactivation domain. Am J Physiol Cell Physiol 2011;300:C1314-C1322.

96 Meij IC, Saar K, van den Heuvel LP, et al: Hereditary isolated renal magnesium loss maps to chromosome 11q23. Am J Hum Genet 1999;64:180-188.

97 Meij IC, Koenderink JB, De Jong JC, et al: Dominant isolated renal magnesium loss is caused by misrouting of the $\mathrm{Na}^{+}, \mathrm{K}^{+}$-ATPase $\gamma$-subunit. Ann NY Acad Sci 2003;986:437443.

98 de Baaij JH, Dorresteijn EM, Hennekam EA, et al: Recurrent FXYD2 p.Gly41Arg mutation in patients with isolated dominant hypomagnesaemia. Nephrol Dial Transplant 2015;30:952-957.

99 Adalat S, Woolf AS, Johnstone KA, et al: HNF1B mutations associate with hypomagnesemia and renal magnesium wasting. J Am Soc Nephrol 2009;20:1123-1131.

100 Faguer S, Decramer S, Chassaing N, et al: Diagnosis, management, and prognosis of HNF1B nephropathy in adulthood. Kidney Int 2011;80:768-776.

101 Arjona FJ, de Baaij JH, Schlingmann KP, et al: CNNM2 mutations cause impaired brain development and seizures in patients with hypomagnesemia. PLoS Genet 2014; 10: e1004267.

102 Suzuki H, Nishizawa T, Tani K, et al: Crystal structure of a claudin provides insight into the architecture of tight junctions. Science 2014;344:304-307.

103 Eshaghi S, Niegowski D, Kohl A, et al: Crystal structure of a divalent metal ion transporter CorA at 2.9 angstrom resolution. Science 2006;313:354-357.

104 Lunin VV, Dobrovetsky E, Khutoreskaya G, et al: Crystal structure of the CorA $\mathrm{Mg}^{2+}$ transporter. Nature 2006;440:833-837.

105 Payandeh J, Pai EF: A structural basis for $\mathrm{Mg}^{2+}$ homeostasis and the CorA translocation cycle. EMBO J 2006;25:3762-3773. 